\title{
24. ISOTOPE COMPOSITIONS OF GASES IN SEDIMENTS FROM THE CHILE CONTINENTAL MARGIN
}

\author{
Amane Waseda ${ }^{2}$ and Borys M. Didyk ${ }^{3}$
}

\begin{abstract}
Molecular and isotope measurements of gases from gas pockets at ODP Leg 141 Sites 859, 860, 861, and 863 are reported. The $\delta^{13} \mathrm{C}$ values of methane range between $-86 \%$ and $-61 \%$. The $\delta \mathrm{D}$ values of methane range between $-249 \%$ and $-163 \%$. The $\mathrm{C}_{1} /\left(\mathrm{C}_{2}+\mathrm{C}_{3}\right)$ ratios of all samples are higher than 300 . These data indicate methane is mainly produced by bacterial activity, and the primary methanogenic pathway is $\mathrm{CO}_{2}$ reduction. The $\delta^{13} \mathrm{C}$ values of ethane range between $-70 \%$ and $-44 \%$. These values are among the lightest carbon isotope values reported for ethane in natural gas, indicating the origin of ethane is also predominantly bacterial. In deeper strata below $200 \mathrm{~m}$ below seafloor (mbsf) at Site 860 , the $\delta^{13} \mathrm{C}$ values of ethane become heavier from $-60 \%$ to $-45 \%$ and the $\mathrm{C}_{1} / \mathrm{C}_{3}$ ratios decrease with increasing depth. This indicates the presence of a small amount of thermogenic hydrocarbons. The low degree of maturation of the organic matter suggest the thermogenic hydrocarbon components are not generated in situ but have migrated from more mature strata, possibly driven by active fluid flow in these strata.
\end{abstract}

\section{INTRODUCTION}

Seismic sections across the Chile margin in the forearc region indicate the presence of bottom-simulating reflectors (BSRs). BSRs are thought to mark the base of a layer of gas hydrates (Shipley et al., 1979), and have been associated with actual recovery of hydrates (Shipley and Didyk, 1982). Hydrates are ice-like solids that contain large concentrations of gas, predominantly methane (Kvenvolden and Barnard, 1983). The hydrate layer is thought to be in pressure-temperature equilibrium with free hydrocarbon gases (Miller et al., 1991). Ocean Drilling Program (ODP) Leg 141 in the vicinity of the Chile Triple Junction (Fig. 1) has, for the first time, intentionally penetrated the base of the hydrate layer. The hydrate layer was penetrated at three sites (Sites 859,860, and 861). Although no frozen gas hydrates were recovered, sediments contained abundant methane at all three sites.

The carbon isotope composition of methane is widely used for the genetic classification of hydrocarbon gases (Rosenfield and Silverman, 1959; Bernard, 1978; Schoell, 1980; Rice and Claypool, 1981). It allows the distinction between bacterial and thermogenic hydrocarbons. Schoell (1980) and Whiticar et al. (1986) have shown additionally that the hydrogen isotope composition of methane in combination with the carbon isotope composition characterizes different pathways of bacterial methane formation. Here, we investigate the genetic characterization of light hydrocarbons by analyses of stable carbon and hydrogen isotope compositions in combination with molecular compositions of gases.

\section{GEOLOGIC SETTING}

At the Chile Triple Junction (Fig. 1) an active spreading ridge and adjacent young oceanic crust are being subducted beneath the continent of South America. During ODP Leg 141, Pliocene to Pleistocene sedimentary sequences were recovered at four sites. Three Sites $(859$, 860 , and 861) were drilled along an east-west dip transect about 35 $\mathrm{km}$ north of the Chile Triple Junction at water depths ranging from 1652 to $2741 \mathrm{~m}$. Site 863 ( $2564 \mathrm{~m}$ water depth) was drilled at the base

\footnotetext{
'Lewis, S.D., Behrmann, J.H.. Musgrave, R.J., and Cande, S.C. (Eds.), 1995. Proc ODP, Sci. Results, 141: College Station, TX (Ocean Drilling Program).

2 JAPEX Research Center, 1-2-1 Hamada, Mihama-ku, Chiba 261, Japan.

${ }^{3}$ Empresa Nacional del Petróleo, Refinería de Petróleos Concón S.A., Casilla 28-D, Viña del Mar, Chile.
}

of a trench-slope basin directly above the subducted spreading axis as a strike transect with Site 859 .

\section{METHODS}

Gas pockets visible in the core through clear plastic core liner were tapped with a hollow punch, and samples were expanded into $20-\mathrm{ml}$ evacuated sample tubes (vacutainers) aboard JOIDES Resolution. The molecular compositions of hydrocarbon gases were determined on a Hewlett-Packard 5890a gas chromatograph.

For the isotope analyses the individual gas components were separated by a gas chromatograph and subsequently combusted to $\mathrm{CO}_{2}$ and $\mathrm{H}_{2} \mathrm{O}$ over $\mathrm{CuO}$ at $850^{\circ} \mathrm{C}$, using a vacuum preparation line (Schoell, 1980). The combustion produced $\mathrm{H}_{2} \mathrm{O}$ is reduced to $\mathrm{H}_{2}$ by reaction with zinc in sealed glass tubes at $480^{\circ} \mathrm{C}$ (Vennemann and O'Neil, 1993).

The stable carbon and hydrogen isotope values of methane were measured using a VG Isotech Sira Series II mass spectrometer. Enough ethane was available from several samples for carbon isotope measurements. Isotope ratios are reported in the usual $\delta$-notation relative to the PDB (Pee Dee Belemnite) standard for carbon and SMOW (Standard Mean Ocean Water) standard for hydrogen:

$$
\delta R_{a}(\% o)=\left\{\left[\left(R_{a} / R_{b}\right)_{\text {sample }} /\left(R_{a} / R_{b}\right)_{\text {standard }}\right]-1\right\} \times 1000,
$$

where $R_{a} / R_{b}$ is ${ }^{13} \mathrm{C} /{ }^{12} \mathrm{C}$ and $\mathrm{D} / \mathrm{H}$, respectively. The reproducibility of isotope values is $\pm 0.15 \%$ for $\delta^{13} \mathrm{C}$ of methane, $\pm 0.3 \%$ for $\delta^{13} \mathrm{C}$ of ethane, and $\pm 3 \%$ for $\delta \mathrm{D}$ of methane.

\section{RESULTS AND DISCUSSION}

Vacutainer gas samples from four sites analyzed in this study are listed by depth of burial in Table $1 . \delta^{13} \mathrm{C}$ values of methane and ethane and $\delta \mathrm{D}$ values of methane determined in this study are reported, as well as the shipboard determination of hydrocarbon composition. Gas pockets frequently appeared and high concentrations of methane were consistently observed at Sites 859,860 , and 861 drilled along the eastwest dip transect. At Site 863 drilled as the strike transect with Site 859 , gas pockets were relatively rare, and concentrations of methane were low in most vacutainer samples. Only two samples had enough methane for isotope analyses at Site 863. Carbon dioxide concentrations are below $0.1 \%(1000 \mathrm{ppm})$ in all samples. We could not measure carbon isotope values of $\mathrm{CO}_{2}$ due to its low concentration. 
Table 1. Molecular composition and isotope data of vacutainer gas samples.

\begin{tabular}{|c|c|c|c|c|c|c|c|c|c|c|}
\hline \multirow[b]{2}{*}{ Core, section } & \multirow{2}{*}{$\begin{array}{l}\text { Depth } \\
\text { (mbsf) }\end{array}$} & \multicolumn{3}{|c|}{ Concentration $(\mathrm{ppm})^{*}$} & \multicolumn{3}{|c|}{ Ratio } & \multicolumn{2}{|c|}{$\delta^{13} \mathrm{C} \%$} & \multirow{2}{*}{$\begin{array}{l}\delta \mathrm{D} \% \\
\mathrm{CH}_{4}\end{array}$} \\
\hline & & $\mathrm{CH}_{4}$ & $\mathrm{C}_{2} \mathrm{H}_{6}$ & $\mathrm{C}_{3} \mathrm{H}_{8}$ & $\mathrm{C}_{1} / \mathrm{C}_{2}$ & $\mathrm{C}_{1} / \mathrm{C}_{3}$ & $\mathrm{C}_{1} /\left(\mathrm{C}_{2}+\mathrm{C}_{3}\right)$ & $\mathrm{CH}_{4}$ & $\mathrm{C}_{2} \mathrm{H}_{6}$ & \\
\hline $\begin{array}{c}141-859 \mathrm{~A}- \\
4 \mathrm{H}-1 \\
5 \mathrm{H}-6\end{array}$ & $\begin{array}{l}17.5 \\
33.5\end{array}$ & $\begin{array}{l}862,231 \\
916,452\end{array}$ & $\begin{array}{l}56 \\
58\end{array}$ & $\begin{array}{l}0 \\
0\end{array}$ & $\begin{array}{l}15,397 \\
15,801\end{array}$ & & $\begin{array}{l}15,397 \\
15,801\end{array}$ & $\begin{array}{l}-69.9 \\
-69.8\end{array}$ & & -183 \\
\hline $\begin{array}{c}141-859 \mathrm{~B}- \\
3 \mathrm{R}-5 \\
10 \mathrm{R}-3 \\
12 \mathrm{R}-3 \\
13 \mathrm{R}-4 \\
16 \mathrm{R}-3 \\
20 \mathrm{R}-1 \\
23 \mathrm{R}-3 \\
27 \mathrm{R}-2 \\
34 \mathrm{R}-2\end{array}$ & $\begin{array}{r}78.0 \\
200.0 \\
220.0 \\
231.0 \\
259.0 \\
294.0 \\
325.0 \\
362.2 \\
430.0\end{array}$ & $\begin{array}{r}880,897 \\
742,056 \\
922,939 \\
944,456 \\
953,223 \\
925,201 \\
131,681 \\
78,759 \\
750,898\end{array}$ & $\begin{array}{r}72 \\
156 \\
275 \\
282 \\
373 \\
367 \\
38 \\
19 \\
320\end{array}$ & $\begin{array}{r}0 \\
7 \\
39 \\
53 \\
152 \\
127 \\
12 \\
8 \\
163\end{array}$ & $\begin{array}{r}12,235 \\
4757 \\
3356 \\
3349 \\
2556 \\
2521 \\
3465 \\
4145 \\
2347\end{array}$ & $\begin{array}{r}106,008 \\
23,665 \\
17,820 \\
6271 \\
7285 \\
10,973 \\
9845 \\
4607\end{array}$ & $\begin{array}{r}12,235 \\
4552 \\
2939 \\
2819 \\
1816 \\
1873 \\
2634 \\
2917 \\
1555\end{array}$ & $\begin{array}{l}-66.2 \\
-66.2 \\
-66.6 \\
-61.7 \\
-65.9 \\
-65.0 \\
-65.8 \\
-63.9 \\
-63.0\end{array}$ & & $\begin{array}{l}-174 \\
-211 \\
-206 \\
-243 \\
-209 \\
-189 \\
-200\end{array}$ \\
\hline $\begin{array}{c}141-860 \mathrm{~B}- \\
4 \mathrm{H}-7 \\
7 \mathrm{H}-5 \\
14 \mathrm{X}-2 \\
17 \mathrm{X}-5 \\
21 \mathrm{X}-1 \\
24 \mathrm{X}-1 \\
25 \mathrm{X}-2 \\
38 \mathrm{X}-2 \\
41 \mathrm{X}-5 \\
43 \mathrm{X}-2 \\
48 \mathrm{X}-4 \\
51 \mathrm{X}-2 \\
53 \mathrm{X}-2 \\
60 \mathrm{X}-2 \\
62 \mathrm{X}-2\end{array}$ & $\begin{array}{r}30.0 \\
56.0 \\
101.0 \\
133.0 \\
153.3 \\
184.4 \\
195.5 \\
321.5 \\
355.1 \\
361.1 \\
411.7 \\
436.3 \\
456.2 \\
514.3 \\
533.1\end{array}$ & $\begin{array}{l}738,541 \\
915,282 \\
578,722 \\
790,414 \\
782,189 \\
809,063 \\
749,855 \\
889,497 \\
960,281 \\
863,584 \\
856,949 \\
685,249 \\
620,622 \\
818,272 \\
970,142\end{array}$ & $\begin{array}{r}8 \\
11 \\
14 \\
56 \\
66 \\
245 \\
371 \\
1800 \\
2126 \\
2308 \\
2399 \\
1636 \\
1714 \\
2198 \\
2917\end{array}$ & $\begin{array}{r}3 \\
4 \\
3 \\
0 \\
0 \\
0 \\
0 \\
26 \\
35 \\
62 \\
53 \\
54 \\
76 \\
126 \\
166\end{array}$ & $\begin{array}{r}92,318 \\
83,207 \\
41,337 \\
14,115 \\
11,851 \\
3302 \\
2021 \\
494 \\
452 \\
374 \\
383 \\
419 \\
362 \\
372 \\
333\end{array}$ & $\begin{array}{r}34,211 \\
27,437 \\
13,929 \\
16,169 \\
12,690 \\
8166 \\
6494 \\
5844\end{array}$ & $\begin{array}{r}67,140 \\
61,019 \\
34,042 \\
14,115 \\
11,851 \\
3302 \\
2021 \\
487 \\
444 \\
364 \\
374 \\
405 \\
347 \\
352 \\
315\end{array}$ & $\begin{array}{l}-72.5 \\
-67.6 \\
-66.7 \\
-65.7 \\
-65.3 \\
-65.2 \\
-64.9 \\
-64.1 \\
-63.5 \\
-62.8 \\
-63.3 \\
-64.2 \\
-62.9 \\
-62.9 \\
-62.8\end{array}$ & $\begin{array}{l}-60.5 \\
-60.7 \\
-59.1 \\
-53.3 \\
-44.4 \\
-46.8 \\
-45.9 \\
-47.0\end{array}$ & $\begin{array}{l}-191 \\
-163 \\
-208 \\
-208 \\
-183 \\
-222 \\
-209 \\
-202 \\
-239 \\
-202 \\
-201 \\
-200 \\
-223\end{array}$ \\
\hline $\begin{array}{c}141-861 \mathrm{~A}- \\
1 \mathrm{H}-6\end{array}$ & 8.7 & 67,077 & 0 & 0 & & & & -85.1 & & -222 \\
\hline $\begin{array}{l}141-861 \mathrm{C}- \\
4 \mathrm{H}-3 \\
7 \mathrm{H}-3 \\
12 \mathrm{X}-2 \\
15 \mathrm{X}-2 \\
17 \mathrm{X}-2 \\
21 \mathrm{X}-1 \\
25 \mathrm{X}-5 \\
32 \mathrm{X}-2 \\
35 \mathrm{X}-3 \\
37 \mathrm{X}-1\end{array}$ & $\begin{array}{r}25.6 \\
54.3 \\
92.2 \\
120.7 \\
140.3 \\
171.4 \\
215.2 \\
258.7 \\
288.3 \\
306.2\end{array}$ & $\begin{array}{l}621,209 \\
661,711 \\
898,750 \\
929,217 \\
966,546 \\
924,548 \\
925,918 \\
876,737 \\
828,978 \\
926,816\end{array}$ & $\begin{array}{r}0 \\
10 \\
65 \\
167 \\
287 \\
573 \\
1404 \\
1593 \\
1381 \\
1533\end{array}$ & $\begin{array}{r}2 \\
2 \\
5 \\
4 \\
2 \\
0 \\
8 \\
8 \\
9 \\
12\end{array}$ & $\begin{array}{r}66,171 \\
13,827 \\
5564 \\
3368 \\
1614 \\
659 \\
550 \\
600 \\
605\end{array}$ & $\begin{array}{r}310,605 \\
330,856 \\
179,750 \\
232,304 \\
483,273 \\
\\
115,740 \\
109,592 \\
92,109 \\
77,235\end{array}$ & $\begin{array}{r}310,605 \\
55,143 \\
12,839 \\
5434 \\
3344 \\
1614 \\
656 \\
548 \\
596 \\
600\end{array}$ & $\begin{array}{l}-77.5 \\
-71.8 \\
-69.9 \\
-69.3 \\
-68.6 \\
-67.7 \\
-65.6 \\
-64.7 \\
-64.4 \\
-64.9\end{array}$ & $\begin{array}{l}-60.9 \\
-64.7 \\
-61.4 \\
-59.1\end{array}$ & $\begin{array}{l}-201 \\
-196 \\
-201 \\
-206 \\
-181 \\
-211\end{array}$ \\
\hline $\begin{array}{c}141-861 \mathrm{D}- \\
6 \mathrm{R}-3 \\
12 \mathrm{R}-2\end{array}$ & $\begin{array}{l}392.4 \\
450.0\end{array}$ & $\begin{array}{l}949,058 \\
924,212\end{array}$ & $\begin{array}{r}1340 \\
716\end{array}$ & $\begin{array}{l}6 \\
3\end{array}$ & $\begin{array}{r}708 \\
1291\end{array}$ & $\begin{array}{l}158,176 \\
308,071\end{array}$ & $\begin{array}{r}705 \\
1285\end{array}$ & $\begin{array}{l}-64.0 \\
-64.6\end{array}$ & -62.1 & $\begin{array}{l}-206 \\
-206\end{array}$ \\
\hline $\begin{array}{c}141-863 \mathrm{~A}- \\
8 X-4 \\
14 X-1\end{array}$ & $\begin{array}{r}70.3 \\
124.5\end{array}$ & $\begin{array}{r}836,885 \\
24,026\end{array}$ & $\begin{array}{r}2118 \\
11\end{array}$ & $\begin{array}{l}0 \\
0\end{array}$ & $\begin{array}{r}395 \\
2184\end{array}$ & & $\begin{array}{r}395 \\
2184\end{array}$ & $\begin{array}{l}-79.7 \\
-66.8\end{array}$ & -69.9 & -227 \\
\hline
\end{tabular}

Note: * = Shipboard measurement. Blanks indicate data not available.

The $\delta^{13} \mathrm{C}$ values of methane range between $-86 \%$ and $-61 \%$ (Table 1). The $\mathrm{C}_{1} /\left(\mathrm{C}_{2}+\mathrm{C}_{3}\right)$ ratios of all vacutainer samples are higher than 300 . Those isotope and molecular compositions indicate methane was mainly produced by bacterial activity (Fig. 2). Bacterial methane formation follows two principal pathways (i.e., $\mathrm{CO}_{2}$ reduction and fermentation; Schoell, 1980; Jenden and Kaplan, 1986; Martens et al., 1986; Whiticar et al., 1986; Burke et al., 1988). The fermentation processes are usually more important in recent freshwater sediments and swamps, while methane formed by $\mathrm{CO}_{2}$ reduction is most common in marine sediments (Whiticar et al., 1986). Recent studies however revealed that the methanogenic pathway is not controlled by depositional environment but mainly controlled by temperature, organic substrate, and age of sediments (Schoell, 1988). $\mathrm{CO}_{2}$ reduction-derived methane and fermentation-derived methane can be differentiated by their deuterium concentration. Fermentationderived methane is characterized by its depletion in deuterium. $\delta \mathrm{D}$ values of vacutainer gas samples in this study range between $-249 \%$ and $-163 \%$ (Table 1 ), indicating methanes were generated by bacterial $\mathrm{CO}_{2}$ reduction (Fig. 3). Methanogenic $\mathrm{CO}_{2}$-reducing bacteria are generally active after sulfate depletion by sulfate-reducing bacteria (Claypool and Kaplan, 1974). This mechanism of methanogenesis is consistent with the observation that relatively low sulfate concentrations in interstitial waters accompany with abundant methane at Sites 859,860 , and 861 , while high concentrations of sulfate with low concentrations of methane are observed at Site 863 (Behrmann, Lewis, Musgrave, et al., 1992).

Methane isotope profiles with depth at Sites 859,860 , and 861 are compiled in Figure 4. The BSR lies at approximately 100, 200, and 250 mbsf (meters below seafloor) at Sites 859, 860, and 861, respectively. No distinct change of the $\delta^{13} \mathrm{C}$ values of methane or molecular compositions are observed at those depths. The $\delta^{13} \mathrm{C}$ values of methane become heavier with increasing depth in the upper $200 \mathrm{~m}$ at all sites. These changes accord with the predictions of the theoretical model, which assumes the bacterial formation of $\mathrm{CH}_{4}$ by reducing $\mathrm{CO}_{2}$ under closed-system conditions (Claypool and Kaplan, 1974). When $\mathrm{CH}_{4}$ is generated in sediments, the $\Sigma \mathrm{CO}_{2}$ reservoir becomes depleted in ${ }^{12} \mathrm{C}$ because of preferential removal of ${ }^{12} \mathrm{C}$-enriched $\mathrm{CO}_{2}$ to form $\mathrm{CH}_{4}$.

The concentrations of ethane range from 0 to $3000 \mathrm{ppm}$. The decrease of $C_{1} / C_{2}$ ratios with increasing depth in the upper $200 \mathrm{~m}$ are observed (Fig. 5). Ethane and higher hydrocarbons generally increase in concentration with depth in other DSDP and ODP cores (Emeis and 


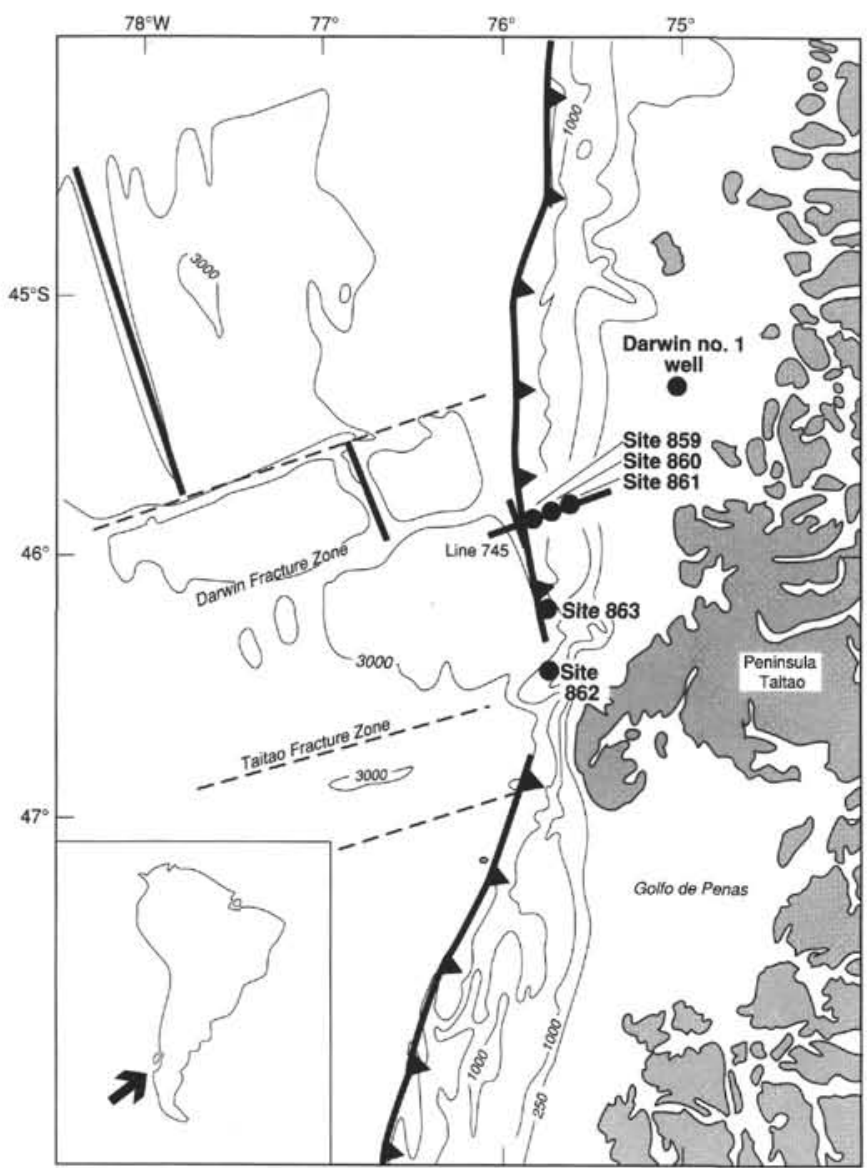

Figure 1. Tectonic sketch map of the Chile Triple Junction and its surroundings showing location of Sites 859, 860, 861, and 863. Solid bold lines indicate spreading segments of the Chile Ridge, separating Nazca Plate (north) and Antarctic Plate (south), barbed line is the frontal thrust of the South American forearc.

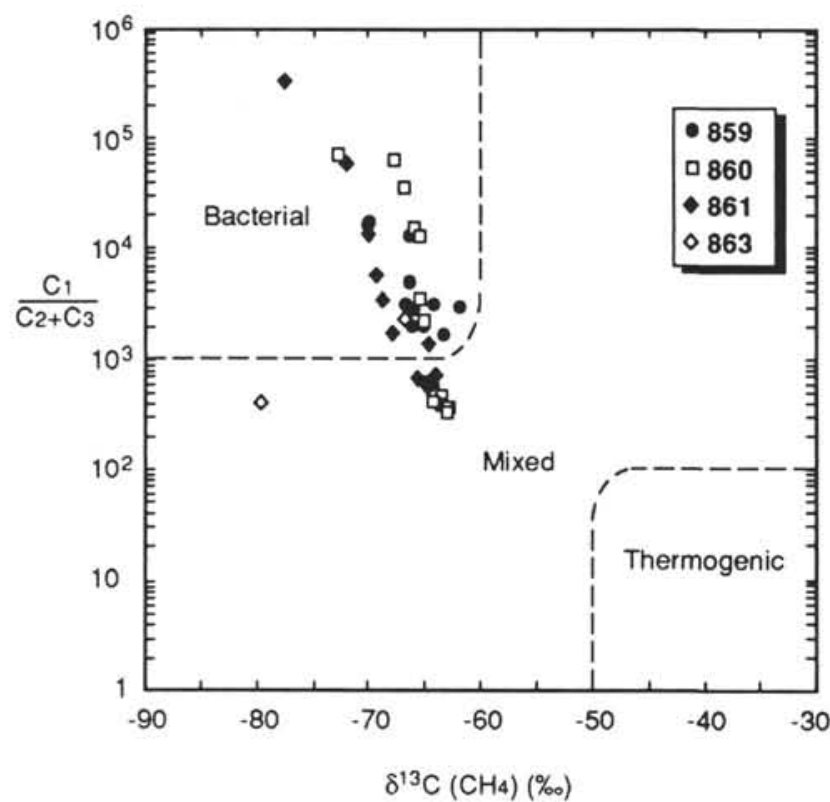

Figure 2. Interpretative plot of molecular ratios vs. carbon isotope compositions of methane from gas pockets, combining Sites $859,860,861$, and 863 (diagram modified after Bernard, 1978).

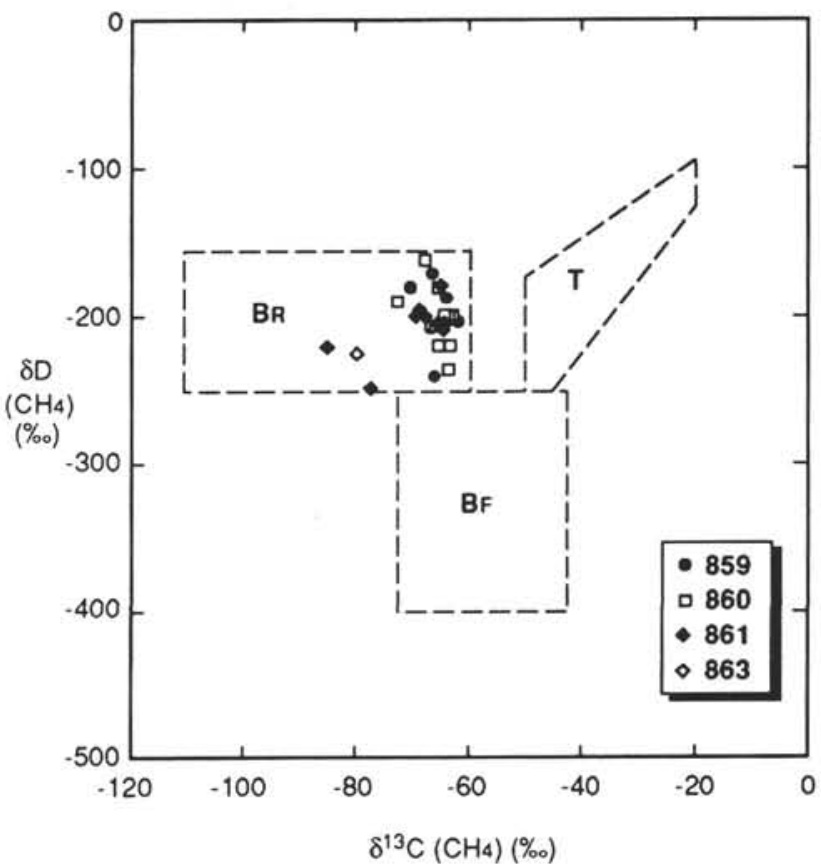

Figure 3. Interpretative plot of hydrogen and carbon isotope compositions of methane from gas pockets, combining Sites $859,860,861$, and 863 (diagram modified after Schoell, 1988). Fields $B R$ and $B F$ are the areas which encompass bacterial methanes that form by $\mathrm{CO}_{2}$ reduction and fermentation, respectively. Field $T$ is the area which encompasses methane of thermogenic origin.

$$
\delta^{13} \mathrm{C}\left(\mathrm{CH}_{4}\right)(\% \circ)
$$

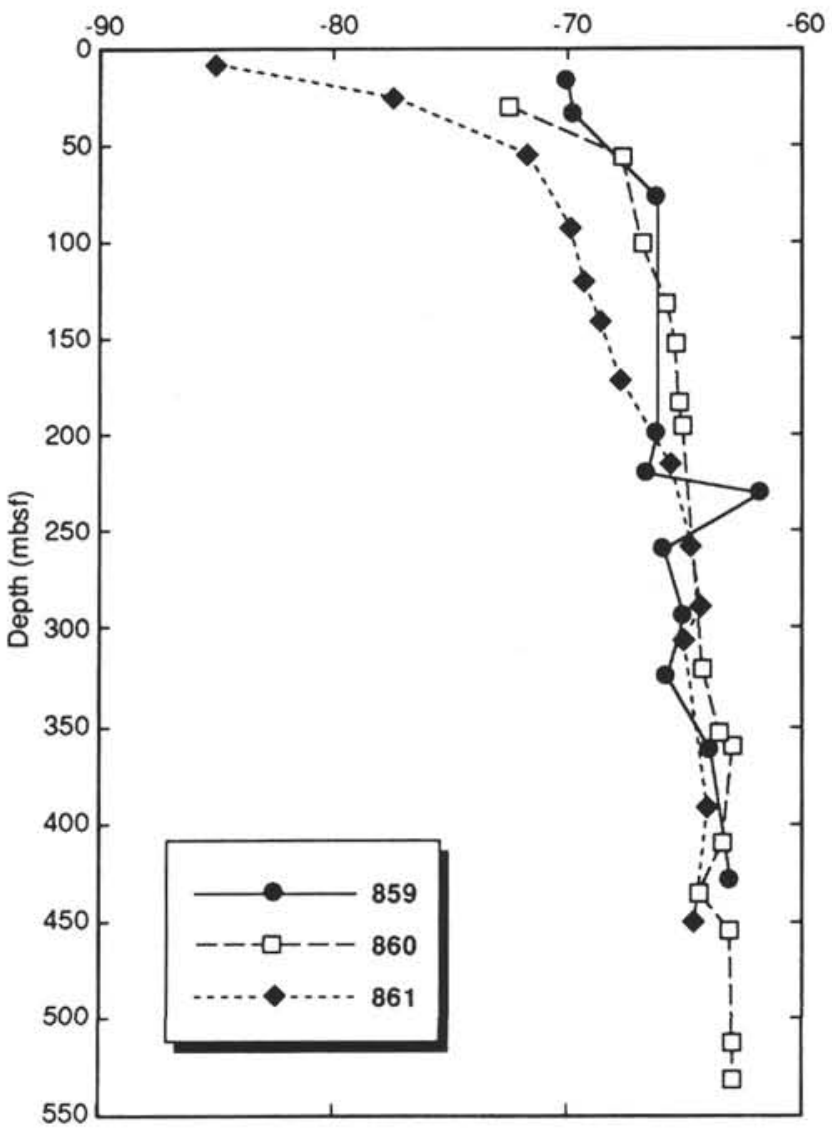

Figure 4. Carbon isotope profile of methanes from gas pockets from Sites 859, 860 , and 861 . 


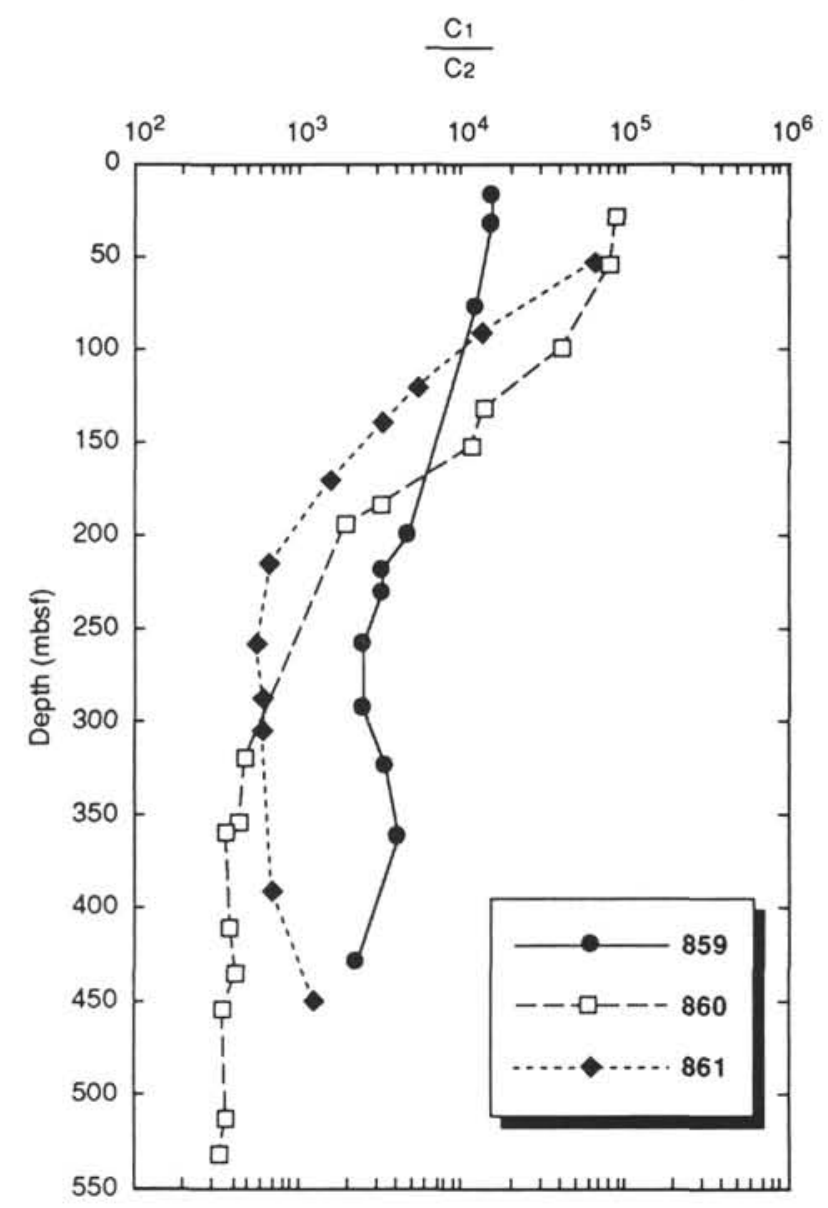

Figure $5 . \mathrm{C}_{1} / \mathrm{C}_{2}$ ratio profile of hydrocarbons from gas pockets at Sites 859 , 860 , and 861 .

Kvenvolden, 1986). Ethane and higher hydrocarbons are generally interpreted as thermogenic components resulting from both thermal degradation of indigenous organic matter in sediments and/or upward migration from deeper, more mature strata. However, active formation of bacterial higher hydrocarbons has been observed in anaerobic bacterial culture experiments (Hunt et al., 1980) and incubation studies of sediments from different aquatic environments (Vogel et al., 1982; Oremland et al., 1988). This kind of experimental evidence, combined with the common observation of small quantities of ethane and higher hydrocarbons in recent marine sediments, has led some authors to suggest bacterial and low temperature chemical processes as a reasonable source for these hydrocarbons (Hunt et al., 1980; Kvenvolden and Redden, 1980; Whelan et al., 1980).

$\delta^{13} \mathrm{C}$ values of ethane were measured on 13 samples below 200 mbsf at Sites 860 and 861 , and one sample at $70 \mathrm{mbsf}$ at Site 863 , ranging between $-70 \%$ and $-44 \%$ (Table 1). The $\delta^{13} \mathrm{C}$ values of ethane of core gases from ODP Leg 84 , Site 570 are fairly uniform, ranging from $-24 \%$ to $-26 \%$ in six sections, indicating a thermogenic origin (Jeffrey et al., 1985), and those values measured on sorbed gases from ODP Leg 112, Sites 679,680 , and 682 range from $-38 \%$ to $-25 \%$ for 22 samples except for one data of $-48.3 \%$, also indicating a thermogenic origin (Whiticar and Suess, 1990). Ethanes of this study are depleted in ${ }^{13} \mathrm{C}$ compared to these data, and the carbon isotope compositions are among the lightest values reported for ethane in natural gas. The $\delta^{13} \mathrm{C}$ values of organic matter in the sediments of this region averages about $-25 \%$ (Waseda et al., this volume). The differences between the $\delta^{13} \mathrm{C}$ values of ethane and organic matter in this region are approximately $20 \%$ to $45 \%$. Such large fractionation can not be explained by thermogenic or low temperature chemical

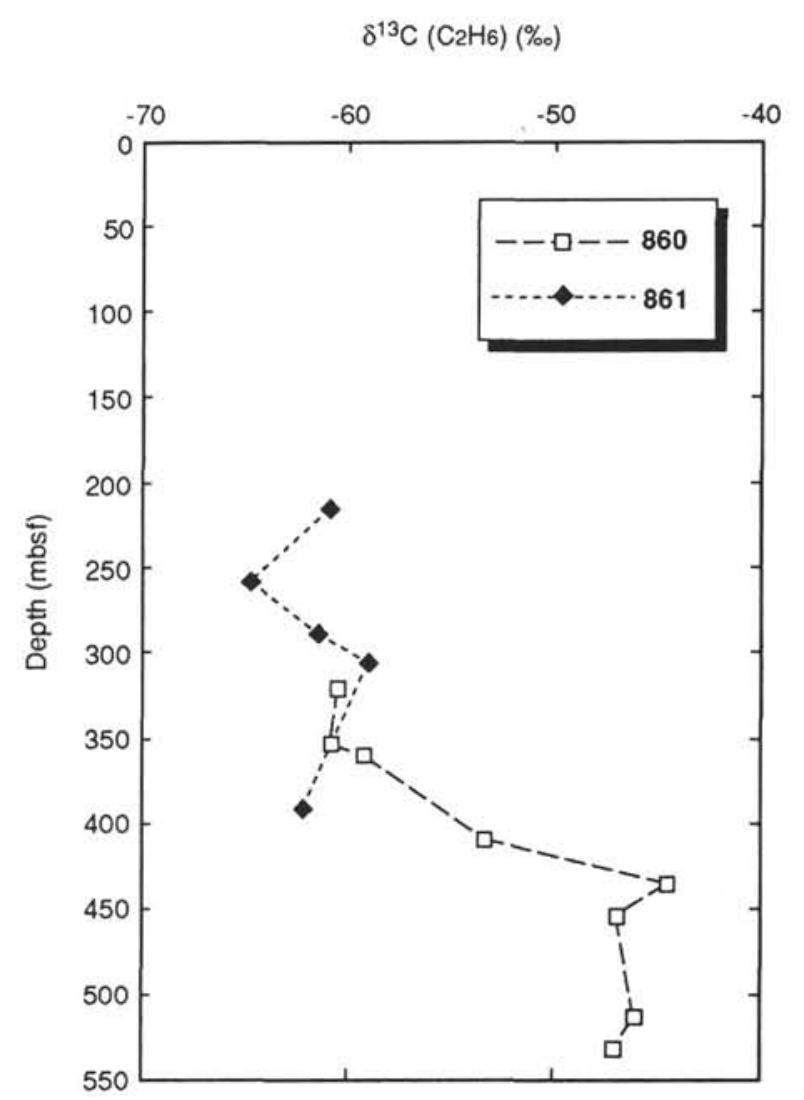

Figure 6. Carbon isotope profile of ethanes from gas pockets at Sites 860 and 861 .

reaction. Therefore, we conclude that the origin of this isotopically light ethane is mainly bacterial. Isotopically light $(-58 \%$ to $-45 \%)$ biogenic ethane has also been reported in natural gas samples from Italy (Mattavelli et al., 1992).

Propane and higher hydrocarbons can also be generated by bacterial activity (Hunt et al., 1980). However, the detection of heavier hydrocarbons extending up to $C_{7}$ in vacutainer and headspace gases in deeper layers below $200 \mathrm{mbsf}$ and presence of well-matured extracted bitumens in some sediment samples strongly suggest the existence of migrated thermogenic hydrocarbons (Behrmann, Lewis, Musgrave, et al., 1992; Didyk et al., this volume). The $\delta^{13} \mathrm{C}$ values of ethane become heavier from $-60 \%$ to $-45 \%$ and the $C_{1} / C_{3}$ ratios decrease with increasing depth at the interval of 350 to $450 \mathrm{mbsf}$ at Site 860 , while the $\delta^{13} \mathrm{C}$ values of ethane are almost constant and the $\mathrm{C}_{1} / \mathrm{C}_{3}$ ratios are also constant, ranging between $10^{5}$ and $10^{6}$ at Site 861 (Figs. 6 and 7). The $\delta^{13} \mathrm{C}$ values of ethane and $C_{1} / C_{3}$ ratios show negative correlation at Site 860 (Fig. 8). If propane is mainly derived from thermogenic decomposition of organic matter, these changes in the $\delta^{13} \mathrm{C}$ values of ethane and $\mathrm{C}_{1} / \mathrm{C}_{3}$ ratios at Site 860 can be explained by the increase of thermogenic hydrocarbon contribution with increasing depth. The low degree of maturation of the organic matter is observed at all sites of Leg 141 in accordance with the shallow depth of burial of the sediments and low bottom hole temperature. We therefore suggest the thermogenic hydrocarbon components are not generated in situ but have migrated from more mature strata.

Since the concentrations of ethane are too low, we could not measure the $\delta^{13} \mathrm{C}$ values of ethane at Site 859. In deeper strata below 200 mbsf, $C_{1} / C_{2}$ ratios at Site 859 are higher than those of Sites 860 and 861 (Fig. 5). On the other hand, $C_{1} / C_{3}$ ratios at Site 859 are lowest among three sites (Fig. 7). Judging from these results, at Site 859, we infer bacterial ethane production is least active and thermogenic hydrocarbon contribution in deeper strata below $200 \mathrm{mbsf}$ is highest among 


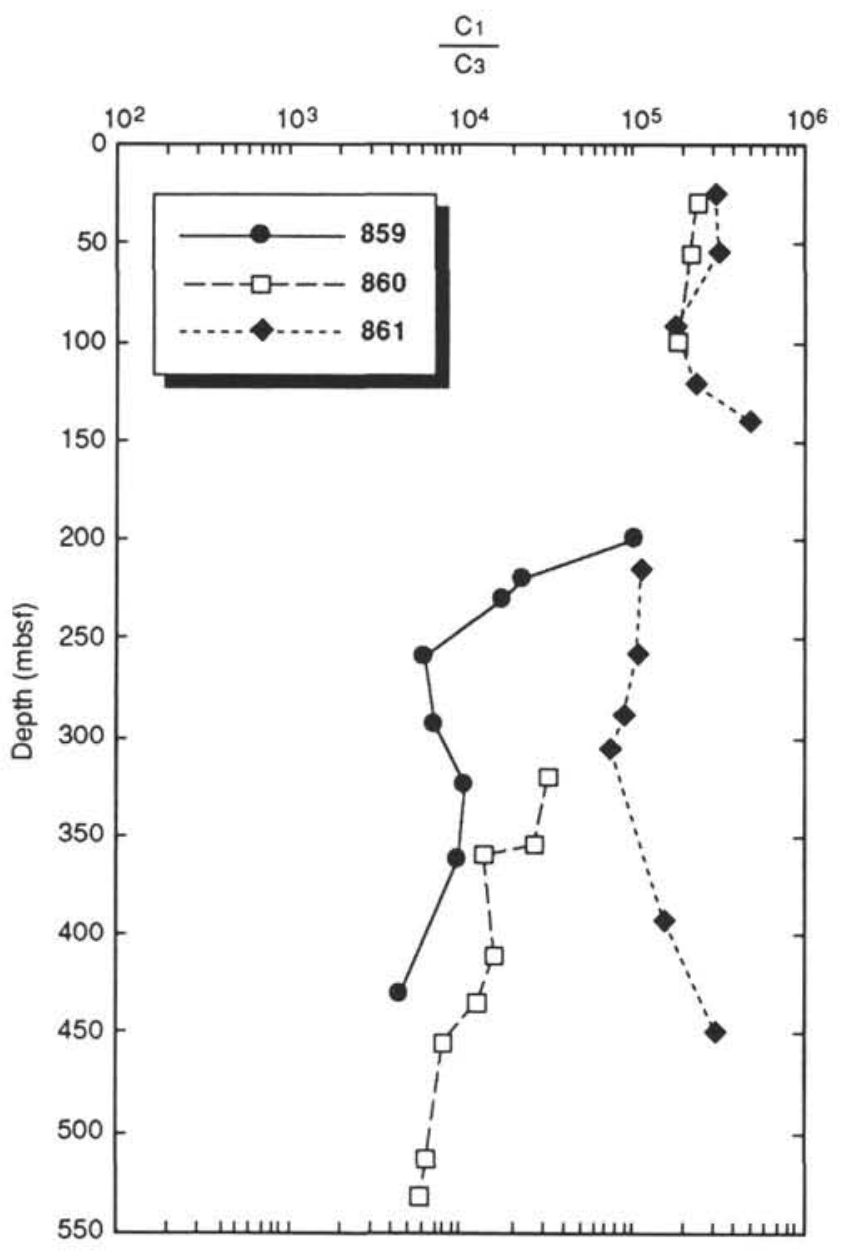

Figure 7. $C_{1} / C_{3}$ ratio profile of hydrocarbons from gas pockets at Sites 859 , 860 , and 861 .

three sites. The methane isotope depth profile at Site 859 is rougher than the profiles at Sites 860 and 861 , and a positive spike is observed at 231 mbsf (Fig. 4). The downhole geothermal gradient at Site 859 is extremely nonlinear downhole, showing active lateral fluid flow, and the evaluation of the temperature data recorded at $240 \mathrm{mbsf}$ shows that the borehole fluid at this depth was substantially hotter, indicating the injection of hot fluids into the borehole from an aquifer of limited stratigraphic thickness in the near vicinity (Shipboard Scientific Party, 1992). The depth of this thermal anomaly almost coincides with the depth of the positive spike on the methane isotope depth profile, indicating thermogenic hydrocarbons have migrated with hot fluids.

To calculate the mixing ratio between bacterial and thermogenic gases, we assume that the isotopic compositions of the thermogenic end member are $-45 \%$ o $\left(\mathrm{CH}_{4}\right)$ and $-29 \%$ o $\left(\mathrm{C}_{2} \mathrm{H}_{6}\right)$, adopted from the isotope data of gas hydrate recovered in Gulf of Mexico whose origin is clearly classified as thermogenic (Brooks et al., 1984), and the molecular composition is $90 \%$ methane, $5 \%$ ethane, and $5 \%$ other gases. The bacterial end member is assumed to be the composition of Sample 141-861C-32X-2, which has the most ${ }^{13} \mathrm{C}$-depleted ethane at Sites 860 and 861 . The mixing line is shown in Figure 9, indicating the contribution of thermogenic gas does not exceed $5 \%$ of total gas in this case.

\section{SUMMARY}

Seismic sections across the Chile margin in the forearc region indicate the presence of bottom-simulating reflectors (BSRs) which

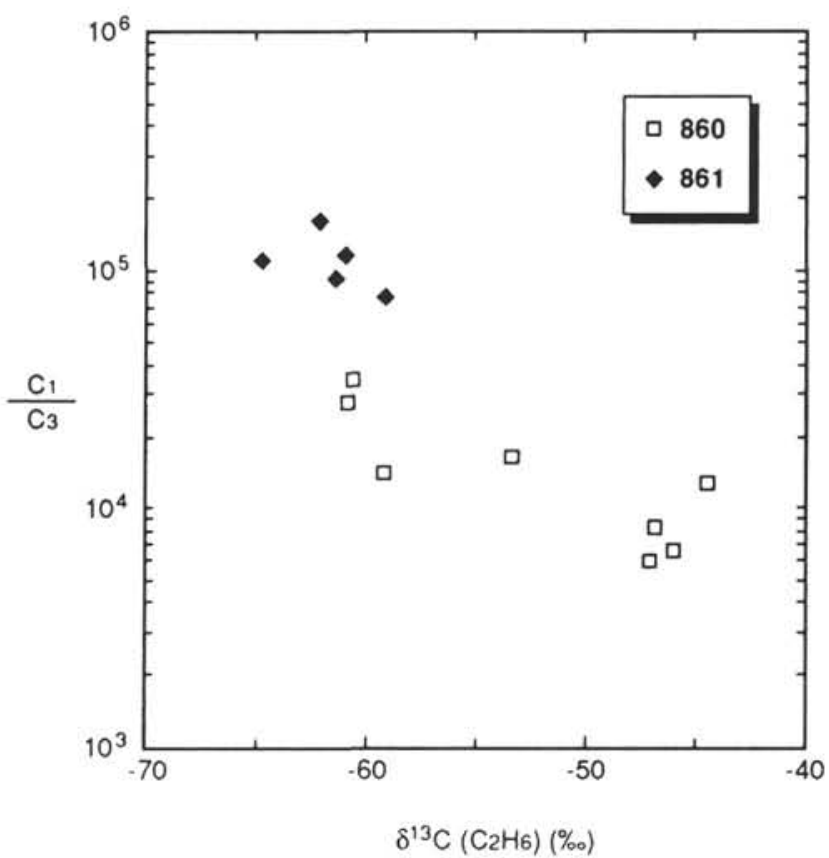

Figure $8 . C_{1} / C_{3}$ ratios and carbon isotope values of ethanes from gas pockets at Sites 860 and 861 .

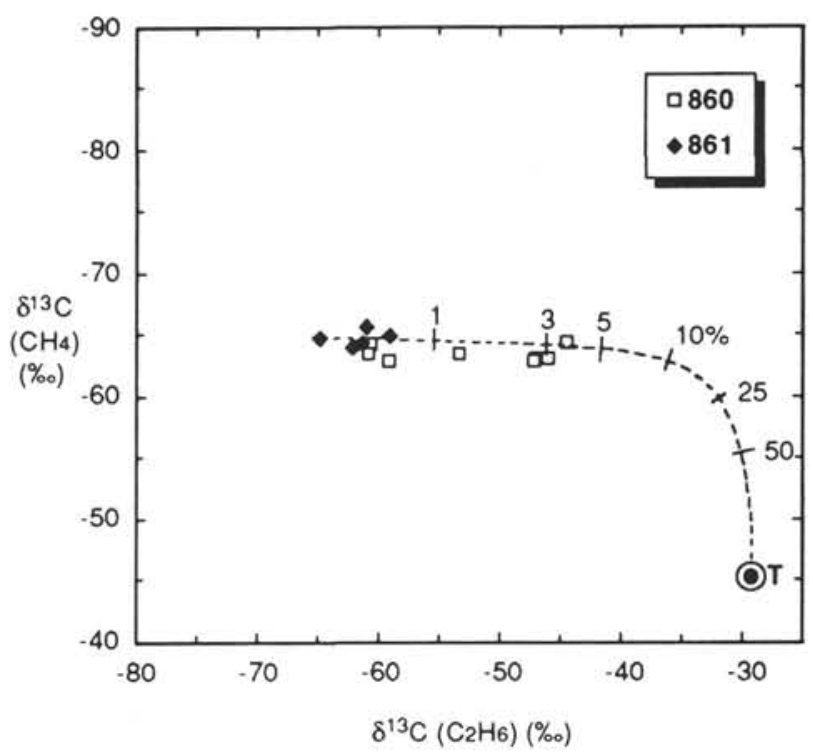

Figure 9. Carbon isotope compositions of methane and ethane from gas pockets at Sites 860 and 861 . Dashed line indicates mixing between bacterial and thermogenic gases, supposing carbon isotope compositions of thermogenic end member $(T)$ are $-45 \%$ (methane) and $-29 \%$ (ethane), and molecular composition is $90 \%$ methane, $5 \%$ ethane, and $5 \%$ other gases. The percentages of thermogenic components in total gases are shown with the mixing line.

are thought to mark the base of a layer of gas hydrates. The hydrate layer was penetrated at three sites (Sites 859,860, and 861). Although no frozen gas hydrates were recovered, sediments contain abundant methane at all three sites. The $\delta^{13} \mathrm{C}$ values of methane range between $-86 \%$ and $-61 \%$. The $\delta \mathrm{D}$ values of methane range between $-249 \%$ and $-163 \%$. The $C_{1} /\left(C_{2}+C_{3}\right)$ ratios of all studied samples are higher than 300 . These data indicate methane is mainly produced by bacterial activity, and the primary methanogenic pathway is $\mathrm{CO}_{2}$ reduction. 
The $\delta^{13} \mathrm{C}$ values of ethane range between $-70 \%$ and $-44 \%$, indicating the origin of ethane is also mainly bacterial.

In deeper strata below $200 \mathrm{mbsf}$ at Site 860 , the $\delta^{13} \mathrm{C}$ values of ethane become heavier from $-60 \%$ to $-45 \%$ and the $C_{1} / C_{3}$ ratios decrease with increasing depth. This indicates the presence of a small amount of thermogenic hydrocarbons. Judging from $C_{1} / C_{3}$ ratios, the contribution of thermogenic gases is highest at Site 859, located nearest to the spreading ridge, and lowest at Site 861 among three sites drilled on the trench slope of the continental margin. The low degree of maturation of the organic matter suggest the thermogenic hydrocarbon component are not generated in situ but has migrated from more mature strata, possibly driven by active fluid flow in these strata.

\section{ACKNOWLEDGMENTS}

We are grateful to Japan Petroleum Exploration Company, Ltd., and Empresa Nacional del Petróleo for allowing us to participate in the Leg 141 cruise and publish this paper. The laboratory assistance of Y. Abe is greatly appreciated. We thank G.E. Claypool and M. Schoell for reviewing the manuscript.

\section{REFERENCES ${ }^{*}$}

Behrmann, J.H., Lewis, S.D., Musgrave, R.J., et al., 1992. Proc. ODP, Init. Repts., 141: College Station, TX (Ocean Drilling Program).

Bernard, B.B., 1978. Light hydrocarbons in marine sediments [Ph.D. dissert.]. Texas A\&M Univ., College Station, TX.

Brooks, J.M., Kennicutt, M.C., II, McDonald, T.J., and Sassen, R., 1984. Thermogenic gas hydrates in the Gulf of Mexico. Science, 225:409-411.

Burke, R.A., Jr., Martens, C.S., and Sackett, W.M., 1988. Seasonal variation of $\mathrm{D} / \mathrm{H}$ and ${ }^{13} \mathrm{C} /{ }^{12} \mathrm{C}$ ratios of microbial methane in surface sediments. Nature, 332:829-831.

Claypool, G.E., and Kaplan, I.R., 1974. The origin and distribution of methane in marine sediments. In Kaplan, I.R. (Ed.), Natural Gases in Marine Sediments: New York (Plenum), 99-139.

Emeis, K.-C., and Kvenvolden, K.A., 1986. Shipboard organic geochemistry on JOIDES Resolution. ODP Tech. Note, 7.

Hunt, J.M., Miller, R.J., and Whelan, J.K., 1980. Formation of $\mathrm{C}_{4}-\mathrm{C}_{7}$ hydrocarbons from bacterial degradation of naturally occurring terpenoids. Nature, 288:577-578.

Jeffrey, A.W.A.,Pflaum, R.C., McDonald, T.J., Brooks, J.M., and Kvenvolden, K.A., 1985. Isotopic analysis of core gases at sites 565-570, Deep Sea Drilling Project Leg 84. In von Huene, R., Aubouin, J., et al., Init. Repts. DSDP, 84: Washington (U.S. Govt. Printing Office), 719-726.

Jenden, P.D., and Kaplan, I.R., 1986. Comparison of microbial gases from the Middle America Trench and Scripps Submarine Canyon: implications for the origin of natural gas. Appl. Geochem., 1:631-646.

Kvenvolden, K.A., and Barnard, L.A., 1983. Hydrates of natural gas in continental margins. In Watkins, J.S., and Drake, C.L. (Eds.), Studies in Continental Margin Geology. AAPG, 34:631-640.

Kvenvolden, K.A., and Redden, G.D., 1980. Hydrocarbon gas in sediment from the shelf, slope, and basin of the Bering Sea. Geochim. Cosmochim. Acta, 44:1145-1150.

Martens, C.S., Blair, N.E., Green, C.D., and Des Marais, D.J., 1986. Seasonal variations in the stable carbon isotopic signature of biogenic methane in a coastal sediment. Science, 233:1300-1303.
Mattavelli, L., Ricchiuto, T., and Martinenghi, C., 1992. Deep isotopic light methane in northern Italy. In Vially, R. (Ed.), Bacterial Gas: Paris (Technip), 121-132.

Miller, J.J., Lee, M.W., and von Huene, R., 1991. An analysis of a seismic reflection from the base of a gas hydrate zone, offshore Peru. AAPG Bull., 75:910-924.

Oremland, R.S., Whiticar, M.J., Strohmaier, F.E., and Kiene, R.P., 1988. Bacterial ethane formation from reduced, ethylated sulfur compounds in anoxic sediments. Geochim. Cosmochim. Acta, 52:1895-1904.

Rice, D.D., and Claypool, G.E., 1981. Generation, accumulation, and resource potential of biogenic gas. AAPG Bull., 65:5-25.

Rosenfield, W.D., and Silverman, S.R., 1959. Carbon isotope fractionation in bacterial production of methane. Science, 130:1658-1659.

Schoell, M., 1980. The hydrogen and carbon isotopic composition of methane from natural gases of various origins. Geochim. Cosmochim. Acta, 44:649-661.

, 1988. Multiple origins of methane in the earth. Chem. Geol., 71:1-10.

Shipboard Scientific Party, 1992. Site 859. In Behrmann, J.H., Lewis, S.D. Musgrave, R.J., et al., Proc. ODP, Init. Repts., 141: College Station, TX (Ocean Drilling Program), 75-157.

Shipley, T.H., and Didyk, B.M., 1982. Occurrence of methane hydrates offshore southern Mexico. In Watkins, J.S., Moore, J.C., et al., Init. Repts. DSDP, 66: Washington (U.S. Govt. Printing Office), 547-555.

Shipley, T.H., Houston, M.H., Buffler, R.T., Shaub, F.J., McMillen, K.J., Ladd, J.W., and Worzel, J.L., 1979. Seismic evidence for widespread possible gas hydrate horizons on continental slopes and rises. AAPG Bull., 63:2204-2213.

Vennemann, T.W., and O'Neil, J.R., 1993. A simple and inexpensive method of hydrogen isotope and water analyses of minerals and rocks based on zinc reagent. Chem. Geol., 103:227-234.

Vogel, T.M., Oremland, R.S., and Kvenvolden, K.A., 1982. Low-temperature formation of hydrocarbon gases in San Francisco Bay sediment (California). Chem. Geol., 37:289-298.

Whelan, J.K., Hunt, J.M., and Berman, J., 1980. Volatile $C_{1}-C_{7}$ organic compounds in surface sediments from Walvis Bay. Geochim. Cosmochim. Acta, 44:1767-1785.

Whiticar, M.J., Faber, E., and Schoell, M., 1986. Biogenic methane formation in marine and freshwater environments: $\mathrm{CO}_{2}$ reduction vs. acetate fermentation-isotope evidence. Geochim. Cosmochim. Acta, 50:693-709.

Whiticar, M.J., and Suess, E., 1990. Characterization of sorbed volatile hydrocarbons from the Peru margin, Leg 112, Sites 679, 680/681, 682, 684, and 686/687. In Suess, E., von Huene, R., et al., Proc. ODP, Sci. Results, 112: College Station, TX (Ocean Drilling Program), 527-538.

\footnotetext{
"Abbreviations for names of organizations and publications in ODP reference lists follow the style given in Chemical Abstracts Service Source Index (published by American Chemical Society).
}

Date of initial receipt: 15 July 1993

Date of acceptance: 23 December 1993

Ms 141SR-024 